\title{
Medicolegal Findings of Rape Victims: A Retrospective Study of 69 cases at a Tertiary Care Hospital in Dhaka City
}

\author{
Palash Kumar Bose', Mamtaz Ara², Md. Syedur Rahaman², \\ Mohammad Jubaidul Kabir ${ }^{4}$, Prodip Biswas ${ }^{5}$

\begin{abstract}
${ }^{1}$ Associate Professor, Department of Forensic Medicine, Enam Medical College, Savar, Dhaka, Bangladesh; ${ }^{2}$ Lecturer, Department of Forensic Medicine, Dhaka Medical College, Dhaka, Bangladesh; ${ }^{3}$ Assistant Professor, Department of Forensic Medicine, Enam Medical College, Savar, Dhaka, Bangladesh; ${ }^{4}$ Associate Professor, Department of Forensic Medicine, Tairunnessa Memorial Medical College, Gazipur, Bangladesh; ${ }^{5}$ Lecturer, Department of Forensic Medicine, Dhaka Medical College, Dhaka, Bangladesh
\end{abstract}

[Received: 15 March 2017; Revised: 27 March 2017; Accepted: 15 April 2017; Published: 1 July 2017]

\begin{abstract}
Background: Proof of rape depends not only in the physical findings of the victims but also to the subjective intentions of the assailants. Objective: The purpose of the present study was to find out the medicolegal findings of rape victims in order to point out the visible loopholes of the procedure. Methodology: This was a cross sectional descriptive type of study which was done in the Dept. of Forensic Medicine, Dhaka Medical College, Dhaka, Bangladesh from January to December 2016 with maintaining ethical issues. Rape cases from 23 police stations of Dhaka Metropolitan area were sent for medicolegal examination and victims who ultimately agreed to do medicolegal examinations were examined and opinions were given regarding the issues. Results: A total number of 69 cases from 23 police stations of Dhaka Metropolitan area were studied. In this study, majority (70.0\%) of the victims was within 11 to 20 years of age and $65.0 \%$ of the victims were unmarried. Almost $68.0 \%$ of the victims were examined within 7 days followed by $32.0 \%$ of the victims after 7 days to beyond one month after rape; however, $48.0 \%$ of the victims showed sign of recent hymeneal tear with bruise and abrasion followed by $52.0 \%$ showed sign of old hymeneal tear. Spermatozoa were not found in any of the specimen of high vaginal swab. Conclusion: In conclusion, teenage unmarried girl are the most common victim of rape cases. [Journal of National Institute of Neurosciences Bangladesh, 2017;3(2): 106-109]
\end{abstract}

Keywords: Rape; medicolegal; victim.

Correspondence: Dr Palash Kumar Bose, Associate Professor, Department of Forensic Medicine, Enam Medical College, Savar, Dhaka, Bangladesh; Email: palashbose223@hotmail.com; Cell No.: +8801717662296

Conflict of interest: There is no conflict of interest relevant to this paper to disclose.

Funding agency: This research project was not funded by any group or any institution.

Contribution to authors: Bose PK \& Ara M were contributed from the protocol preparation upto report writing. Rahaman MS, Kabir MJ \& Biswas P were involved in the manuscript writing and revision.

How to cite this article: Bose PK, Ara M, Rahaman MS, Kabir MJ, Biswas P. Medicolegal Findings of Rape Victims: A Retrospective Study of 69 cases at a Tertiary Care Hospital in Dhaka City. J Natl Inst Neurosci Bangladesh, 2017;3(2): 106-109

Copyright: @2017. Bose et al. Published by Journal of National Institute of Neurosciences Bangladesh. This article is published under the Creative Commons CC BY-NC License (https://creativecommons.org/licenses/by-nc/4.0/). This license permits use, distribution and reproduction in any medium, provided the original work is properly cited, and is not used for commercial purposes

\section{Introduction}

The word 'rape' is derived from latin term 'rapio' which means to seize. Thus rape literally implies forcible seizure $^{1}$. Rape is defined as physically forced or otherwise coerced penetration - even if slight - of the vulva or anus, using a penis, other body parts or an object. The attempt to do so is known as attempted rape ${ }^{2}$. No age is immune of rape. But children are more frequenly raped due to their less resistance along with the belief that venereal diseases are cured by sexual intercourse with a virgin ${ }^{3}$. In many cases, positive physical findings may not be found in alleged rape. Rape can occur without causing any injury and as such negative evidence does not exclude rape ${ }^{3}$.The doctor should mention only the negative facts; but should not give his opinion that rape has not been committed. Corroboration by eye witness or circumstantial evidence is necessary in such cases ${ }^{4}$.

Rape is a heinous crime that destroys the hope and aspiration of a victim. It is such a complex issue that 
cannot be demonstrated easily. Proof of rape depends not only in the physical findings of the victims but also to the subjective intentions of the assailants. Moreover, in many times, negative physical findings along with lack of witness of the incidence, create problems in courts of law to bring out justice for the victims as everybody is innocent until incidence is proved beyond reasonable doubt in the court.

\section{Methodology}

This was a descriptive type of cross-sectional study conducted in the Department of Forensic Medicine at Dhaka Medical College, Dhaka, Bangladesh from January to December 2016 with maintaining ethical issues. Rape victims who agreed to do medicolegal examinations were recorded as victims of alleged sexual assaults. Victims of alleged rape cases from 23 Metropolitan police stations of Dhaka, Bangladesh were sent for medicolegal examinations within the above mentioned period. After physical examination, radiological report and microbiological report opinion was given whether the signs of forceful sexual intercourse were present or not.

\section{Results}

A total number of 69 cases from 23 police stations of Dhaka Metropolitan area were studied. Table 1 showed that $70 \%$ of the victims was belonged to 11 to 20 years of age group followed by 21 to 30 years of age $14.0 \%$.

Table 1: Age Variation in Rape Victims ( $\mathrm{n}=69$ )

\begin{tabular}{lcc}
\hline Age Group & Frequency & Percentage \\
\hline 0 to 10 Years & 8 & 12.0 \\
11 to 20 Years & 48 & 70.0 \\
21 to 30 Years & 10 & 14.0 \\
More than 31 Years & 3 & 4.0 \\
Total & $\mathbf{6 9}$ & $\mathbf{1 0 0 . 0}$ \\
\hline
\end{tabular}

Table 2 showed that majority (almost $65 \%$ ) of the victms was unmarried.

Table 2: Marital Status of Rape Victims ( $n=69)$

\begin{tabular}{lcc}
\hline Marital Status & Frequency & Percentage \\
\hline Married & 24 & 35.0 \\
Unmarried & 45 & 65.0 \\
Total & $\mathbf{6 9}$ & $\mathbf{1 0 0 . 0}$ \\
\hline
\end{tabular}

Tables 3 showed that majority of the victims $(68 \%)$ were examined within 7 days after rape. Of them $23 \%$ of the victims were examined in same day after rape followed by same $23 \%$ in 4 th to 7 th day of rape.
Table 3: Time of examination of victims after rape $(n=69)$

\begin{tabular}{lcc}
\hline Time of Examination & Frequency & Percentage \\
\hline Same day & 16 & 23 \\
Second day & 10 & 15 \\
3rd day & 5 & 7 \\
4th to 7th & 16 & 23 \\
After 1 week to 1 month & 17 & 25 \\
Beyond 1 month & 5 & 7 \\
Total & $\mathbf{6 9}$ & $\mathbf{1 0 0 . 0}$ \\
\hline
\end{tabular}

But majority almost $25 \%$ of the victims was examined after 1 week to within 1 month followed by $7 \%$ even beyond 1 month.

Table 4: Findings of Rape Victims after Physical Examination $(\mathrm{n}=69)$

\begin{tabular}{lcc}
\hline Genital findings & Frequency & Percentage \\
\hline $\begin{array}{l}\text { Recent hymen tear with } \\
\text { bruise and abrasion }\end{array}$ & 33 & 48 \\
$\begin{array}{l}\text { Old hymeneal tear with } \\
\text { no bruise and abraion }\end{array}$ & 36 & 52 \\
Total & $\mathbf{6 9}$ & $\mathbf{1 0 0 . 0}$ \\
\hline
\end{tabular}

Table 4 showed that recent forceful sexual intercourse was found in $48 \%$ cases.

But majority (almost 52.0\%) of the victims did not show any positive physical findings of forceful sexual intercourse.

Table 5: Microbiological Reports Regarding Spermatozoa Found or Not $(n=69)$

\begin{tabular}{lcc}
\hline Report & Frequency & Percentage \\
\hline $\begin{array}{l}\text { No spermatozoa } \\
\text { found }\end{array}$ & 69 & 100.0 \\
\hline
\end{tabular}

Table 5 showed that no spermatozoa were found in any specimen of high vaginal swab.

\section{Discussion}

The magnitude of rape or sexual harassment is high all over the world. However, it comes a little in front of us most of the times. In the majority of countries with available data; less than $40 \%$ of the women who experience sexual assault seek help of any sort. Among who do, most work to family and friends and very few look to formal institutions and mechanisms, such as police and health services. Less than $10 \%$ of those women seeking no help for experience of volume sought help by appealing to the police ${ }^{5}$. The under reporting of cases of sexual assaults are mainly due to social stigma; prejudice with regard to the chances of marriage, publicity in press, embarrassment in court, doubt in local law enforcement, risk of losing the love 
and respect of society ${ }^{6}$.

In this study, it has been found that majority $(70.0 \%)$ of the victims was 11 to 20 years of age and $65.0 \%$ of the victims were unmarried. It reflects that young, unmarried girls are usually targeted for rape; $45.0 \%$ of the victims was examined within 3 days after rape. According to table 3, majority, almost $48.0 \%$ of the victims were examined after 3 days to within one month after rape followed by $7.0 \%$ beyond one month. That is why, signs of forceful sexual intercourse were supposed to be absent in majority cases; $52 \%$ of the victims presented with old hymeneal tear with no signs of abrasion and bruise and $48 \%$ of the victims showed recent hymen tear with abrasion and bruise. Spermatozoa were not found in our study in any of the specimen of high vaginal swab.

Saha et $\mathrm{al}^{7}$ reported that $53.94 \%$ of the victims' age was within 16 to 20 years followed by $26.32 \%$ belonged to $11-15$ years. So, majority, $80.26 \%$ of the victims were 11 to 20 years of age and $71.05 \%$ victims were unmarried. Majority of the victims $(65.79 \%)$ had the signs of recent hymen tear. Ali et $\mathrm{al}^{8}$ in their study showed that majority $(60.0 \%)$ of the victims was within 11 to 20 years of age and $64.8 \%$ of the victims were unmarried. Significant percentage $(59.0 \%)$ of the victims was sent within 3 days of rape for medicolegal examination. But positive physical findings were found only in $27.5 \%$ cases. Majority ( $72.4 \%$ ) had no signs of forceful sexual intercourse. Another study by Al Azad et $\mathrm{al}^{9}$ reported that majority $(69.57 \%)$ of the victims were within 11 to 20 years of age and $78.69 \%$ victims were unmarried. $38.69 \%$ of the victims were sent for medicolegal examination within same day of rape. However, as a whole half $(50.0 \%)$ of the victims were sent within 3 days for medicolegal examination. The rest half were sent beyond 3days to 4 weeks.

In a study conducted by Arif et al ${ }^{10}$ that $60.8 \%$ of the victims were within 11 to 20 years of age and $70.9 \%$ of the victims were unmarried. $24.3 \%$ of the victims were presented for medicolegal examination within 24 to 48 hours of incidents but as a whole, only $45.1 \%$ of the victims were sent within 3 days of the incident and the majority, $55 \%$ were sent after 3 days to more than 1 month. Majority of the victims $(77.6 \%)$ showed old hymen tears. Spermatozoa were found in $18.2 \%$ of the cases.

Vadysighe et $\mathrm{al}^{11}$ showed that $43 \%$ of the victims were 12 to 16 years of age followed by 16 to 20 years $21 \%$. So, majority $(64.0 \%)$ of the victims were within 12 to 20 years of age. Only $29.0 \%$ of the victims were sent within 3 days of incident for medicolegal examination.
Significant percentage $(71.0 \%)$ of the victims were sent after 3days to beyond 1 month of incident for medicilegal opinion. Akinlusi et $\mathrm{a}^{12}$ showed that $83.6 \%$ were below 19 years and over $60.0 \%$ of victims presented after 24 hours of assault.

Spermatozoa were not found in this present study in any cases among the high vaginal swab which is similar to Al-Azad et $\mathrm{al}^{9}$. Absence of spermatozoa in the high vaginal swab does not mean that sexual intercourse has not taken place. These may be due to non-emission, aspermia, previous vasectomy, very old age or poor technique by the examining doctor ${ }^{13}$. Moreover, ejaculation outside vagina, using barrier method can be the factor of failure of detection of spermatozoa in high vaginal swab. Spermatozoa were found in $17.6 \%$ and $30.3 \%$ cases reported by Islam et a ${ }^{14}$ and Grossin et a $l^{15}$ respectively.

\section{Conclusion}

Finally, it can be said that this study reflects that teenage unmarried girls are usually targeted for rape. But, majority of the victims were examined after 3 days to within one month after rape. That is why, signs of forceful sexual intercourse were supposed to be absent in majority cases. Spermatozoa were not found in our study in any of the specimen of high vaginal swab.

\section{References}

1. Vij K. Medicolegal examination of the living In:Textbook of forensic medicine and toxicology: principles and practice, 6 th ed. Reed Elsevier Pvt. Ltd. New Delhi, 2014;297-299

2. Sexual Offences Chapter-6. World Health Organization, 2002. Retrieved on January, 2017 [Avaiable at: www.who.int/violence_injury_prevention/violence/global_campaign/.../chap6.pdf] 3. Reddy KSN, Murty OP. Sexual offence In: The essentials of forensic medicine and toxicology, 33rd ed. Jaypee Brothers Medical Publishers (P) Ltd, New Delhi, 2014;411-417

4. Shepherd R. Sexual offences In: Simpson's Forensic Medicine,12th ed. Arnold, London, 2003, pp.128-132

5. United Nations Economic and Social Affairs 2015. The world's Women: Trends and Statistics, pp. 159 [Available at: www.unwomen.org/en/what-we-do/ending-violence-against-women/facts-and-figures. Retrieved on: January 2017]

6. Malhotra N, Sood M. Sexual Assault, a neglected public health problem in developed world. International Journal of Obstetrics and Gynaecology 2000;71:257-258

7. Saha KP, Rahman M, Mahmud S, Monsur A, Chakrabarty PK. Medico legal aspect of rape. TAJ Journal of Teachers Association 2009;22(1):111-114

8. Ali N, Akhter S, Hossain N, Khan NT. Rape in Rural Bangladesh. Delta Med Col J 2015;3(1):31-35

9. Al-Azad MAS, Rahman Z, Ahmad M, Wahab MA, Ali M, Khalil MI. Socio-demographic characteristics of alleged sexual assault (Rape) cases in Dhaka City. JAFMC Bangladesh 2011;7(2):21-24 10. Arif M, Ahmed M, Hanif F 2014. Natural sexual offences: medicolegal assessment in Punjab. Professional Med J 2014;21(5):980-986 
11. Vadysighe AN, Senasinghe DPP, Attygalle U, Abeysekara AMG, Gunesena MDP, Ratnayake RMUC, et al. An analytical study on socio-demographic and medicolegal factors of victims of sexual assault from the Central and Sabaragamuwa provinces in Srilanka. Srilanka J For Med, Sci Law 2015;6(1):12-20

12. Akinlusi FM, Rabiu KA, Olawepo TA, Adewunmi AA, Ottun TA, Akinola OI. Sexual assault in Lagos, Nigeria: a five year retrospective review. BMC Women's Health 2014;14:115

13. Parikh CK. Natural sexual offences In: Parikh's textbook of medical jurisprudence, forensic medicine and toxicology. 6th edn.
CBS Publishers and Distributors Pvt. Ltd., New Delhi, 2014;pp.5.29-5.44

14. Islam MN, See KL, Ting LC, Khan J. Pattern of sexual offences attended accident and emergency department of HUSM from year 2000 to 2003: a retrospective study. Malaysian Journal of Medical sciences 2006;13(1):30-6

15. Grossin C, Sibille I, Grandmaison GIDI, Banasr A, Brion F, Durigon M. Analysis of 418 cases of sexual assault. Forensic Science Int 2003;131:358-62 